\title{
North Korea: From Failing towards Reforming State?
}

\author{
Joachim Ahrens
}

\author{
Private University of Applied Sciences Goettingen \\ Weender Strasse 3-7 \\ 37073 Goettingen \\ Germany
}

E-mail: ahrens@pfh-goettingen.de

Phone: +4955154700116

Paper to be presented at the AEA/KAEA Session "North Korean Economy at a Crossroads"

Annual Meeting of the Allied Social Sciences Association, Chicago, USA, 5 - 7 January 2007

\begin{abstract}
According to most criteria, North Korea would be classified as a failing state. More often than not the country's destiny has been predicted as collapse, chaos, and in the end, absorption by South Korea. However, so far the Kim Jong-il regime proved viable and cultivated the art to survive within a globalizing world without opening up. More recently, North Korean authorities appeared to revive an affinity towards South Korea's sunshine policy. What is more, the country even seemed to initiate some rudimentary and cautious market-oriented reforms. If these are signs for a policy change, they are definitely not straightforward and they come with considerable uncertainties and risks. Especially, North Korea's nuclear threat potential, its opaque international bargaining strategy, and its reliance on exports of military goods for hard currency revenues represent key obstacles.

And yet, the North Korean elite, South Korean authorities, and the rest of the world do have a vital interest in avoiding an apocalypse on the Korean peninsula. All parties may have an interest in the maintenance of a politically sovereign, economically reforming state. This essay seeks to sketch a politically feasible and economically effective reform strategy for North Korea from a governance perspective. The main argument states that effective integration and economic transition of North Korea crucially depend on the emergence of specific transitional institutions which lead to efficiency gains and enhance the incentive compatibility of ruling the country and pursuing the nations's welfare.
\end{abstract}

JEL classification: O53, P26, P45

Draft version, comments welcome

December 2006 


\title{
North Korea: From Failing towards Reforming State?
}

\author{
Joachim Ahrens
}

\section{Introduction}

According to most criteria, North Korea would be classified as a failing state. More often than not the country's destiny has been predicted as collapse, chaos, and in the end, absorption by South Korea. However, so far the Kim Jong-il regime proved viable and cultivated the art to survive within a globalizing world without opening up. More recently, however, North Korean authorities appeared to revive an affinity towards South Korea's sunshine policy. What is more, the country even seemed to initiate some rudimentary and cautious market-oriented reforms. If these are signs for a policy change, they are definitely not straightforward and they come with considerable uncertainties and risks. Especially, North Korea's nuclear threat potential, its opaque international bargaining strategy, and its reliance on exports of military goods for hard currency revenues represent key obstacles.

And yet, the North Korean elite, South Korean authorities, and the rest of the world do have a vital interest in avoiding an apocalypse on the Korean peninsula. All parties may have an interest in the maintenance of a politically sovereign, economically reforming state in the North. This essay seeks to sketch a politically feasible and economically effective reform strategy for North Korea from a governance perspective. The main argument states that effective integration and economic transition of North Korea do not necessarily presuppose a fundamental regime change towards a Western-style democratic polity with best-practice market institutions, but crucially depend on the emergence of specific transitional institutions which lead to efficiency gains and enhance the incentive compatibility of ruling the country and pursuing the nations's welfare.

The paper is structured as follows: The next chapter investigates the question of whether or not the DPRK is a failed state the destiny of which is collapse and absorption by South Korea. Arguing that North Korea is not a failed, but at best a failing state, the third chapter addresses the follow-up question of what it may take from a governance perspective to become a reforming state. Subsequently, it will be argued that an appropriate governance structure, which aligns the incentives of political elites and private economic actors, needs to be based on Chinese-type 
transitional institutions in order to foster economic transition, development, and growth. Finally, such an approach should be reinforced by a strategy that helps to share the economic and social benefits of growth between all stakeholders.

\section{North Korea - a failed state?}

Since the early 1990s the terms failed states and failing states have become catch phrases in academic debates and analyses as well as in policymaking circles and in jounalism. As Maass and Mepham (2004: 5) point out: "State failure takes many different forms and goes under a variety of different labels. 'Failed states', 'failing states', 'states at risk of failure', 'rogue states', 'poor performers', 'Low Income Countries under Stress (LICUS) - these are just some of the descriptive terms that have been used to define and conceptualise it." Other related terms include 'fragile states', 'crisis states', or 'states at risk of instability' (Woodward 2006).

Some analysts associate a failed state with an absence of government power and define it as a state "that loses the control of a territory or the monopoly of legitimate force, lacks the capacity to make collective decisions or deliver public services, presides over a society that relies on the black market, or fails to collect taxes" (Varga Llosa 2005: 1). Moreover, failed states may not only threaten regional, but also international security (Woodward 2006). Other obervers such as Alvaro Varga Llosa (2005) argue that it is not the lack of state strength or government power, but rather an excess of government power which contributes to the emergence of a failed state.

Furthermore, the label 'failed state' is sometimes used (or better: abused) for distinct political purposes in order to generate pressure on the respective authorities and opposition forces to undergo political transitions towards a certain politico-administrative model which the critics appear to have in mind and which often shows striking similarities to a 'best-practice model of Western-style democratic capitalism'.

However, from numerous institutional analyses as well as practical experience, it follows that a one-size-fits-all solution does not exist. Today most serious academics would agree that uniform strategies of institution-, nation- or state-building are doomed to fail as will unreflected applications of original Washington-Consensus-type policies in the realm of economic reform. A blueprint to overcome political, social, and economic underdevelopment, rent seeking, corruption, nepotism, and state capture is simply not available (Debiel et al. 2005). 
The analysis of the causes and consequences of fragile statehood is a highly complex issue along a number of different dimensions. Therefore, a need for differentiation in investigating failing or failed states exists. In this context, the Washington-based think tank Fund for Peace developed the so-called Failed States Index, an instrument that helps to formulate a more precise description of the state-instability phenomenon. Based on twelve economic, social, political as well as military indicators, numerous countries are ranked with respect to their vulnerability to societal dysfunction and violent conflict. ${ }^{1}$ Basically, the index is assessing country risk allowing, in its disaggregated version, to diagnose even "pockets of failure" within countries which are otherwise relatively stable and exhibit state strength in distinct realms.

The twelve indicators, which reflect different dimensions along which state failure is assessed, comprise:

I1 mounting demographic pressures;

I2 massive movement of refugees and IDPs;

I3 legacy of vengeance -seeking group grievance;

I4 chronic and sustained human flight;

I5 uneven economic development along group lines;

I6 sharp and/or severe economic decline;

I7 criminalization or delegitimization of the state;

I8 progressive deterioration of public services;

I9 widespread violation of human rights;

I10 security apparatus as 'state within a state';

I11 rise of factionalized elites;

I12 intervention of other states or external actors.

Based on individual scores ranging from 0 (best) to 10 (worst), North Korea is ranked $14^{\text {th }}$ on a list including 148 countries (Figure 1). Regardless of the absolute values, it shows that the country performs weak in all dimensions except for the categories I2 and I4; refugees and human flight have not (yet) become as dramatic as in some other states such as Sudan or Chad. The most critical indicator values (see numbers in parentheses) have been found for the dimensions

For a detailed description of the underlying methodology and the complete country ranking visit http://www.fundforpeace.org. 
I5: uneven economic development along group lines (9);I6: sharp and/or severe economic decline (9.5);I7: criminalization or delegitimization of the state (9.8);I8: progressive deterioration of public services (9.5); andI9: $\quad$ widespread violation of human rights (9.5).

\section{Figure 1: Failed States Index 2006}

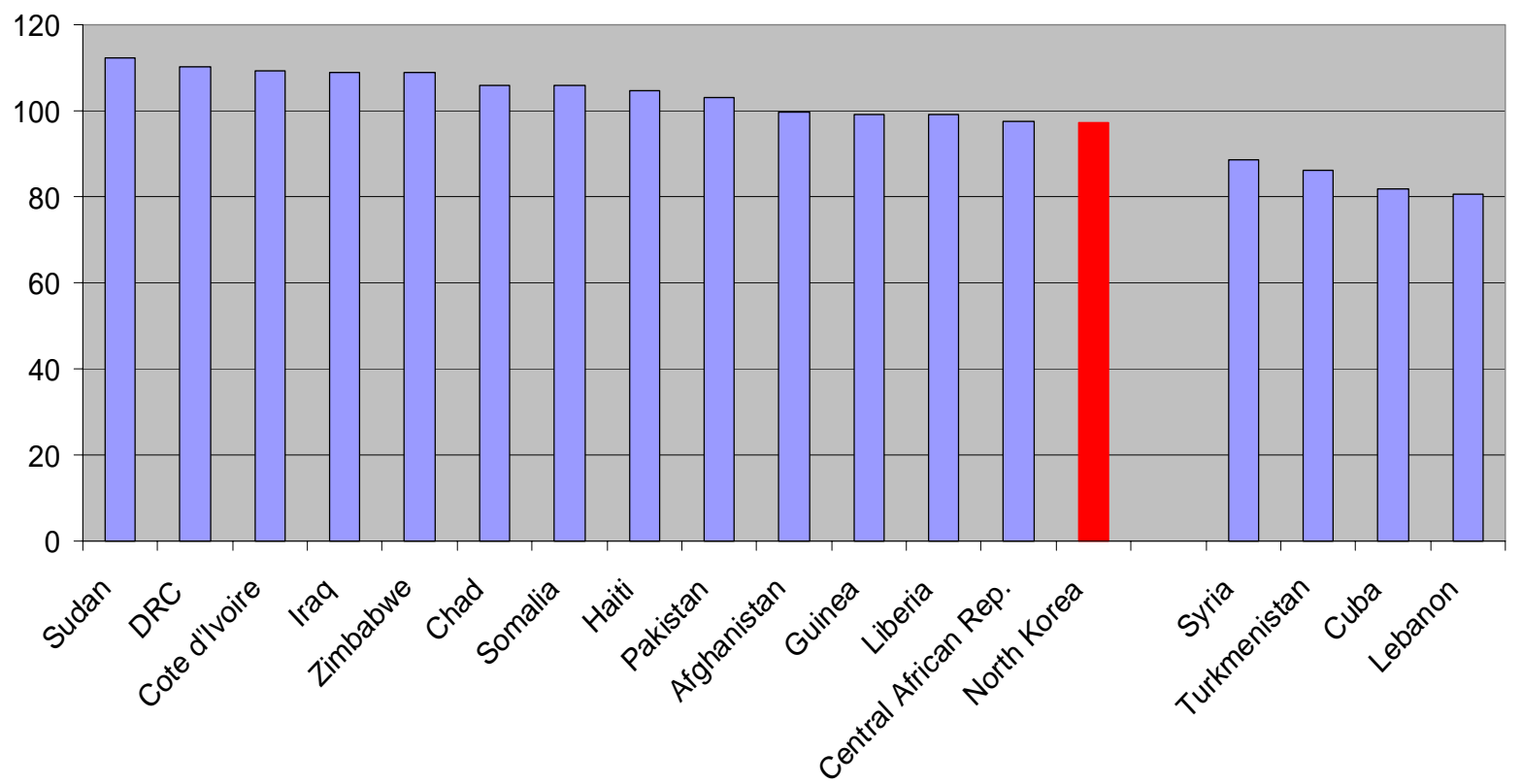

Source: The Fund for Peace (2006); http://fundforpeace.org

The index also reveals that failing states are located along a continuum between failed states and stable, viable, legitimized and capable states. States can fail to various degrees and along different dimensions. A state, which cannot perform any of its functions (i.e. ensuring law and order, providing public goods, exerting monopoly power with respect to its terrain), is a failed state. North Korea, e.g., clearly shows competent state action in a very limited number of fields such as managing military technology or bargaining effectively with foreign governments. The regime also has effective control over its territory, and it enjoys a monopoly on the use of force. On the other hand, the government cannot feed its people or provide basic public services, and it is not perceived as legitimate by many internal and any external actors (Maass and Mepham 2004). However, so far the regime managed to survive and to uphold its power without having been seriously challenged internally or externally.

Therefore, we start with the premise that today's North Korea is a failing, but not (yet) a failed state. Hence, there are different future development trajectories in the cards for the Kim Jong-il regime - ranging from a conflict-cum-collapse scenario to a muddling-through approach 
to a genuine gradual economic reform strategy. Analysts should not rule out any of these scenarios. But for regional and international security reasons and due to the need to enhance political and economic stability in Northeast Asia, the gradual reform scenario deserves particular attention.

\section{On the political economy of a reforming state}

Thinking about reforms in North Korea needs to be based on several binding side conditions. To be politically feasible, reforms cannot question the political regime per se. Therefore, reforms need to be restricted to an economic transition. Most importantly, reforms must

- $\quad$ not undermine the power of the political elite;

- not question the sovereignty of the state;

- $\quad$ be possible with decent ideological shifts;

- $\quad$ be in the interest of the political leadership; and

- not create losers.

This implies that only gradual, piecemeal economic and institutional reforms are feasible. The following discussion seeks to elaborate the components and the sequence of such gradual reforms which are economically effective and politically acceptable to the country's leadership. Based on general considerations relating to crafting a politico-institutional foundation of a reforming state, the approach - frequently supported in the literature - to apply a best-practice governance approach is rejected. Instead, we argue for a country- and time-specific reform path based on socalled transitional institutions and inspired by the Chinese experience with respect to economic transition.

\subsection{The politico-institutional foundation of a reforming state}

Numerous studies of the politcal economy of policy reform and economic transition found that effective reform and transition towards a market-oriented economy requires credible, possibly institutionalized commitments of policymakers as well as a minimum administrative capacity of state institutions and sufficient political and technical capabilities of authorities to formulate and 
implement public policies. These necessaties have been conceptualized through the notion of good governance, which is underlying the process of policymaking.

Recent research on governance and its impact on economic performance significantly increased our understanding of the constituent characteristics of such a politico-institutional foundation of policy formulation and implementation. ${ }^{2}$ Country experiences as well as empirical cross-country studies showed that it is not the regime type per se (i.e., democracy or authoritarian regime) which is the key to successful economic transition and growth. Effective governance can exist in both democratic and non-democratic settings and and all stages of economic development and transition. The quality of institutions and their interplay as well as the interrelations between state and private actors are more important than the political regime. Economic and administrative institutions have proved to be crucial determinants for the quality of policymaking. Therefore, it appears to be safe to conclude that the relationship between the quality of institutions and economic performance is based on an indirect influence, that works through the quality of policymaking and the related expectations of private economic agents.

North $(1990,1997)$ and other institutional and political economists have forcefully argued that it is primarily institutions which provide individuals with specific incentives for individual and group action and affect political and economic exchange. Institutional arrangements also determine the formation and implementation of policies. From that perspective, a proper understanding of governance, that relates to policymaking and economic performance, needs to go beyond the narrower conceptions of either corporate governance or public governance. While corporate governance in a Williamsonian understanding relates to a microperspective on the firm and on private ordering, and public governance is frequently limited to public sector management, the following considerations are based on a concept which conceives governance as "the capacity of the institutional matrix (in which individual actors, organizations and policy makers interact) to implement public policies, enforce rules and regulations, and to improve private-sector coordination". 3

Hence, governance is not a synonym for government. Rather, it relates to institutions associated with governability and accounts for institutional variety as well as its importance for state capacity in conducting policy reform (Ebner 2005). In this context, governance clearly focuses on the quality of public policy and its impact on economic performance and transition. A

See, e.g., Kaufman et al. $(1999,2003)$ and Ahrens (2002) and the literature referred to therein.

Ahrens (2002, p. 128); regarding these considerations see further Williamson (1985, 1995), Ebner (2005), and Kaul (2001). 
country's governance structure consists of institutional arrangements and political processes of formulating and implementing policy goals and applying appropriate instruments, thereby relying on the coordination of diverse actors in the public as well as the private sector. From that perspective, a governance structure exhibits characteristics of a collective good. It is provided by various actors which influence public policymaking in a top-down as well as a bottom-up manner. These actors include public and private domestic organizations such as government agencies, administrative units or companies and trade associations. They also comprise external actors like the International Monetary Fund (IMF), the World Trade Organization (WTO) or foreign governments. The interaction of these actors affects institution building and enforcement in different areas including the management of the public sector, the interface of the public realm and the private sector, the formation of economic institutions as well as the institutional design which determines how a country is integrated into international structures. All of these areas are important for the initiation, formulation and implementation of transformation policies (see Figure 2). These actors' activities are linked through formal and informal institutional arrangements for cooperation, coordination, and consultation. Usually, the government (or possibly a single decisionmaking entity therein) is the main and most powerful actor due to its coercive power and its capacities for institution building and enforcement. In addition, the politico-administrative institutions of a governance structure play a key role, because they determine how different actors are involved in political processes and what kinds of economic reforms are politically feasible. But the state is not a monolithic entity - it is itself a complex, multifaceted organization the internal structure of which represents a complicated nexus of institutions which provide incentives (and disincentives) for political decision makers and bureaucrats to formulate and implement public policies (Ahrens 2002, Ebner 2005). 
Figure 2: A stylized model of governance: realms and players

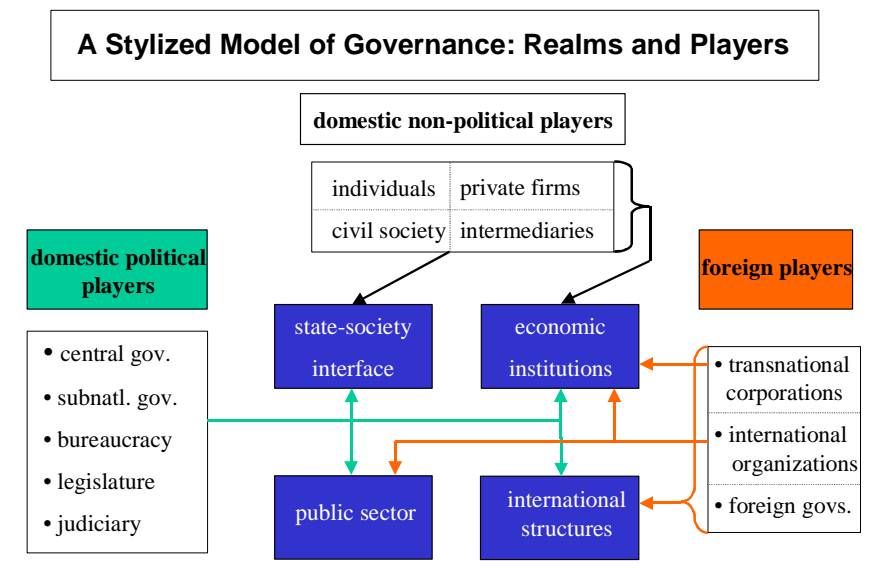

The quality of governance as it is defined in this essay does not depend on a specific regime type. It does not presuppose either a parliamentarly or a presidential system of government. It does not even assume a democratic system or presuppose a benevolent autocratic system. The notion of governance focuses on the quality of institutions which are necessary to implement marketoriented policies and to foster private-sector coordination.

In this context; four pillars, which constitute a market-enhancing governance structure (MEGS), can be distinguished ${ }^{4}$ : First, the state needs to be sufficiently strong to implement policies and protect property rights and to prevent state capture by particularistic interests; secondly, the state needs to be adequately limited to prevent predatory behavior, rent seeking and corruption, of politicians and public officials; thirdly, particularly in transition economies it is also important that the public sector is subject to sustained capacity building in order to create appropriate technical and administrative skills to implement policies; and fourthly, principal economic institutions have to be established which constitute market exchange and foster economic growth.

\section{Creating a strong state}

In many transition economies, the state has lacked the capacity to implement policies and to (impartially) enforce laws and regulations. In many vcases, it has not been capable of preventing

$4 \quad$ For a detailed discussion of these pillars, see Ahrens (2002) and the references therein. The following arguments as well as the considerations in the subsequent section draw heavily from Ahrens (2006a and b). 
public officials from corruptive behavior and influential pressure groups from rent-seeking and distorting economic policies. Such a state is weak in Myrdal's (1989) sense. ${ }^{5}$ Moreover, in order to exploit specialization advantages and to cope with the complexity of structural reforms, the government needs to delegate authority to the public administration, subnational jurisdictions, and private actors. This, in turn, creates principal-agent problems. Delegation causes information asymmetries and bears the risk that the agents do not act in the interest of the principal (the government) and pursue their own interests. Without a systematic control over public officials, policy and institutional reforms might be implemented by one bureau while another one counteracts them. As a consequence, economic agents would no longer trust in the government's ability to implement and enforce the policies according to its announcements. This may result in a system in which corruption and nepotism prevail so that the weak state might turn to become a predatory one (Root 2001). Therefore, a strong state is required that ensures stable, transparent, and predictable policymaking. Within a strong state apparatus, government officials and policymakers show a high degree of autonomy, i.e. they act sufficiently unaffected by vested interests of private actors. A further important factor is the establishment of a highly capable Weberian-type public administration acting relatively autonomously (Evans 1995).

\section{Limiting the state}

A strong government, however, which protects citizens' rights, is usually also powerful enough violate those rights. In order to overcome this dilemma, a strong government must be limited. Public authorities need to be sufficiently strong to protect the rights of investors, workers, and consumers, but at the same time they must be constitutionally or otherwise restricted from infringing upon these rights. This presupposes institutional safeguards which tie policymakers' hands when narrow interests seek to alter laws and regulations at the expense of society. Such a binding mechanism should be designed so that limits are not only imposed on the present, but also on future governments. This is achieved by designing political institutions in a way that incentive structures for politicians and public officials are established which ensure that it is less costly for them to stick to the rules of the game than violating them (Root 2001). This appears as an unalterable precondition to secure a credible commitment of a government to sustained market-oriented policy reform.

\footnotetext{
Regarding these deficiencies in numerous PSCs, see, e.g., the recent Transition Reports of the European Bank of Reconstruction and Development.
} 
In order to avoid predatory behavior and to reduce opportunism of government officials and bureaucrats, horizontal institutional checks (e.g., in the form of separation of powers) as well as vertical institutional checks (including decentralization and federalism) appear to be adequate, if not perfect, means. Relating to the former, the agenda control of one agency may be limited by giving veto power to at least one other public or private organization. In addition, an independent judicial system can contribute to make governments and bureaucrats stick to the rules of the game. Institutions that establish the rule of law contribute to lower transaction costs if they foster transparent and predictable economic and political processes and limit corruption and rentseeking. In addition, independent watchdog organizations may contribute to enhance government accountability. With respect to vertical institutional checks and balances, the concept of marketpreserving federalism (MPF) is expedient. Finally, the exposure of the domestic economy to competition on world markets as well as membership in international organizations such as the IMF or the WTO can help to limit the power of governments (Qian 1999a/1999b, Ahrens 2002).

\section{Creating capacity for policy implementation and rule enforcement}

A further key constituent of a MEGS is capacity building. While narrow definitions interpret capacity building as improving the skills of public servants, broad definitions risk blurring the edges between the notions of capacity building and governance (World Bank 2000). In this study, capacity building encompasses those activities which enhance the credibility, predictability, and transparency of public-sector organizations and individuals. Capacity building can help to improve the effectiveness and efficiency of governmental activities. It includes institutional reform, organizational strengthening, and human resource development. Institution building refers to replacing existing institutions with more efficient ones; organizational change relates to altering organizational structures to better suit the new set of institutions; and human resource development refers to training people to act in line with new institutions and organizational structures (Grindle 1997). The objective of capacity building is to enhance the credibility of the public sector through the creation of a professional public administration that ideally establishes, complies with, and secures the economic order and its legal and regulatory framework, dissipates relevant information, and effectively pursues the tasks it has been given authority to do. Essential institutional arrangements, including the introduction of hard budget constraints and meritocratic elements within the bureaucracy, are to be prioritized contingent on country-specific necessities when conducting institutional reform (Ahrens 2002). 


\section{Building economic institutions}

Formal economic institutions constitute the fourth pillar of a MEGS, because they determine the incentives for economic activity in a country. Therefore, the answer to the question as to why some countries are more developed than others is closely related to the set and the quality of a country's economic institutions (Acemoglu et al. 2004).

The German ordo-liberal school analyzes the institutional framework of a market economy according to distinct constituent principles, all of which support the functioning of a market-price system as an economy's main allocation mechanism (Streit and Wohlgemuth 1997; Wagener 2004). The constitutive properties comprise the protection of private property rights, the guarantee of free market entry and exit (open markets), the freedom of contract, the stability of the monetary system, liability for economic actions, and the steadiness and predictability of economic policymaking (Eucken 1952/1990). The state should only intervene in the market if the intervention is market compatible and does not harm the price mechanism. In order to maintain a functioning economic and social order, regulating principles complement the constituent ones. Market failures are to be corrected through anti-trust institutions or interventions in order to guarantee the functioning of the price mechanism. In order to maintain social peace, income distribution needs to be corrected, social safety nets to be installed and employee rights to be protected (ibid.).

With regard to economic institution building, policymakers can basically follow two different strategies. First, the government adopts the economic institutional matrix from a 'bestpractice country'. Such a strategy has often failed in history, because social norms, values, and beliefs change more slowly than formal economic and political institutions and thus impede a big-bang approach of institutional change (Roland 2004). Alternatively, governments may use local knowledge to build economic institutions in a more gradual process. This might, on the one hand, meet country-specific needs and be compatible with persisting informal institutions. But on the other hand, it does only to a limited extent capitalize on experiences of developed nations with institution building.

These four pillars of a market-enhancing governance structure are usually not perfectly built in any country. And, in fact, there are no blueprints regarding single institutional components of each pillar and with respect to the process of developing such institutions. The history of today's 
most advanced economies in Europe and North America as well as contemporary experiences of successful transition economies such as China or Russia indicate that effective governance is highly country- and time-specific. This also implies that MEGS cannot be completely crafted by governments, political advisors, or international organizations.

\subsection{Towards best-practice governance?}

Basically, a huge number of institutional arrangements exists which can contribute to bring about a MEGS. Different institutions, e.g., can help to establish a strong state or to limit a strong government. Regarding the former, one may think of anti-corruption agencies, meritocratic recruitment and promotion rules in the public sector, centralized economic planning boards among others; with respect to the latter participatory policymaking as well as general, free, and secret elections as in a Western-style democracy come to mind. Moreover, regarding capacity building in the public sector, many scholars usually think of introducing new management rules or market-oriented procurement regulation into the public administration, and finally with respect to economic institutions private property rights and competition rules are usually given high priority in transformation policy.

Due to the complexity of systemic transition, policymakers as well as academics are frequently tempted to identify best-practice approaches from successful reformers. This was true at the beginning of the 1990s when the so-called Washington Consensus (originally compiled for debt-ridden countries in Latin America in the 1980s) was sought to be applied to many economies in transition. Several years later, new insights emerged due to the experiences in early transition phases. In fact, the Washington-Consensus type of policies emphasized important policy measures in an era of transition (such as stabilization and liberalization), but they neglected institution building (except for crafting private property rights). Particularly, the failure of IMF-led transition programs in countries such as Russia revealed that liberalization-cumprivatization approaches did not automatically bring about efficient and sustainable market structures. Without consideration of political and societal conditions as well as institutional restrictions, an efficient and politically feasible transition policy could not be implemented. ${ }^{6}$

6 Of course, some scholars had already taken those difficulties in policy formulation and implementation into consideration in early stages of transition. Some scholars questioned the Washington Consensus approach per se, whereas others postulated an explicit evolutionary-institutional transition concept which focused on microeconomic aspects such as asymmetric information and agency problems among others; see, e.g., Roland (2000) or Murrell (1995). This strand of analysis and policy advice, however, did not gain significant influence in the policymaking circles of CEE. 
This was taken into account during the subsequent debate about so-called second-generation reforms, when institutions were considered essential also from the viewpoint of analysts with a more neoclassical background. The next step was to identify best-practice institutions in order to make policy reform effective, market forces work, and eventually overcome government failure. An emerging consensus among scholars of economic development and transition as well as international organizations suggests that a distinct set of core institutions can be identified which spur economic growth and sustained development. ${ }^{7}$ According to this view, key institutions, which should be crafted as quickly as possible, include, among others, the rule of law, private property rights, an independent judiciary enforcing private contracts impartially, thorough regulation to safeguard economic competition, sound corporate governance structures and a transparent financial architecture, undistorted markets characterized by low rents, social insurance, democratic accountability and participation rules, checks and balances, and strengthening civil society (Khan 2002, Bardhan 2005).

Basically, these Western-style best-practice institutions may represent a useful reference point for less developed countries and transition economies. However, experts advising governments on institution building have often neglected the processes of how these institutions are developed, agreed upon, and enforced. Frequently, initial conditions persisting in a country are ignored and policy advice is driven by the presumed desirable goal of transition (i.e., Western-style best-practice institutions), and not by the search for a politically feasible path towards that goal (Qian 2003). In particular, it is hardly discussed that institution building needs to be driven by political actors in numerous cases and, hence, that is must be in the interest of these actors to craft those institutions.

Note in this context, that policy advisors as well as the international donor community may be also adaptive to new experiences and insights. The World Bank (2000), e.g., explicitly concedes that so-called best-practice models regarding governance and institution building may not be feasible. 
Figure 3: Orthodox thinking about the relation between governance and growth

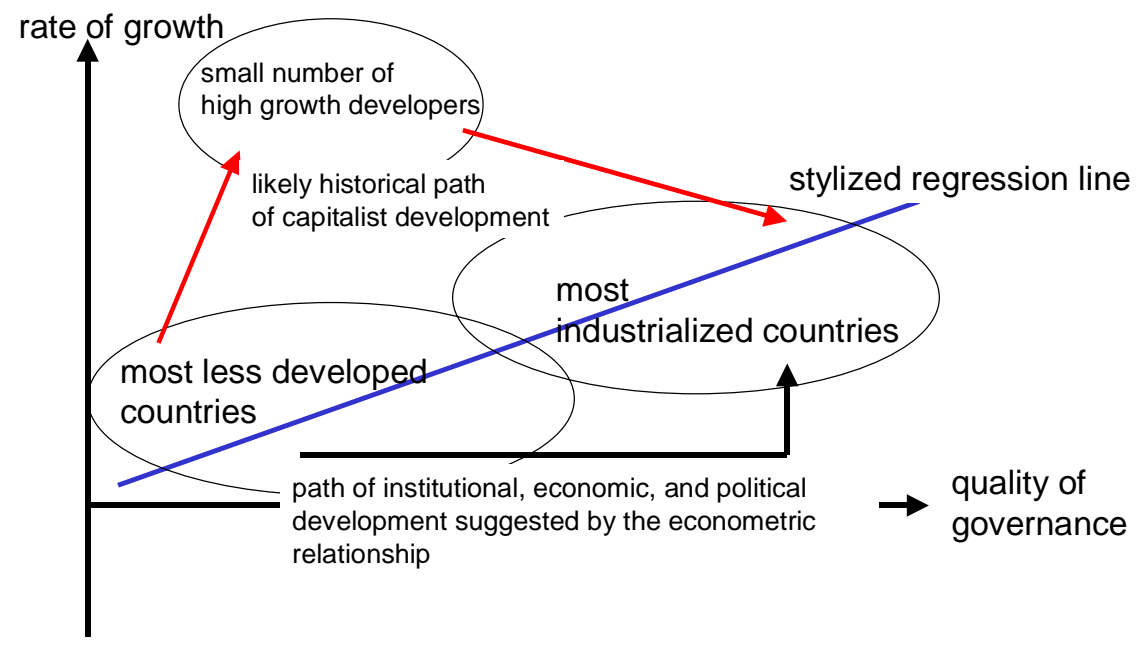

Source: Khan (2002), modified.

The "liberal-market consensus" (Khan 2002) appears to suggest a benchmark for institution building which is to be achieved in a straightforward linear trajectory of institutional reform as quickly as possible (see Figure 3). However, the small number of highly-performing economies especially in Asia (but also in other parts of the world) followed a different path of development (and so did today's industrialized countries at the early stages of their economic development and growth processes). ${ }^{8}$ They realized extraordinarily high levels of growth and sustained them over a considerable period of time without fulfilling the criteria of Western-style institution building.

Therefore, yet another consensus began to emerge even more recently which goes beyond institutions. Since it is not single rules but the interplay of economic and political institutions being crucial for economic performance, scholars and practitioners came to agree that governance matters. And again, we observe a new quest - this time for best-practice governance structures. Against the background of the liberal-market consensus, which still dominates numerous policy circles, think tanks, and academia, a governance structure, which is argued to be a precondition to structural change and sustained economic growth, ought to be modelled according to a Western-

$8 \quad$ See, e.g., Khan (2002) and Chang (2002). 
style governance model. This view is frequently supported by the fact that numerous people see a liberal democracy with particular social, economic, and environmental standards of advanced economies not only as an instrument fostering economic development, but as an end in itself. ${ }^{9}$

Elsewhere, I argued that best-practice governance structures cannot be defined due to different initial conditions faced by transition countries, different economic structures and stages of economic development, different political interests and different societal preferences (Ahrens 2002 and 2006b). Instead, in the countries of Central and Eastern Europe as well as in China and Vietnam distinct governance structures have been emerging. In these successfully transforming countries, the emerging governance structures have proved to be market-enhancing and, hence, served as catalysts to economic transition. In all of these cases, country-specific MEGS contributed to positively affect the respective government's credibility and improved the attraction of these countries as a destination of investment and production despite significantly different initial conditions and economic transformation strategies. Although these cases differed from one another, they fit into the analytical comparative concept of governance outlined above. Even if none of the countries was able to bring about a perfect MEGS, governance-related institutions in all countries scored comparatively high according to the dimensions credibility, predictability, and transparency - 'comparatively' relating to a comparison with other countries at a similar stage of economic development or in a similar phase of transition. Also, the relatively good performance in terms of institutional quality has not necessarily related to all pillars of a MEGS equally. But in sum, the emerging governance structures have been conceived to be growth-enhancing and sustainable over time from the viewpoint of foreign and domestic investors, and the respective governments proved to be able to credibly commit to honor investors' rights and to foster long-term growth.

\footnotetext{
9 See, e.g., the arguments in Khan (2002), Feng (2003), and Kaufman et al. (2003).
} 


\section{Figure 4: The governance, democratization, and growth nexus}

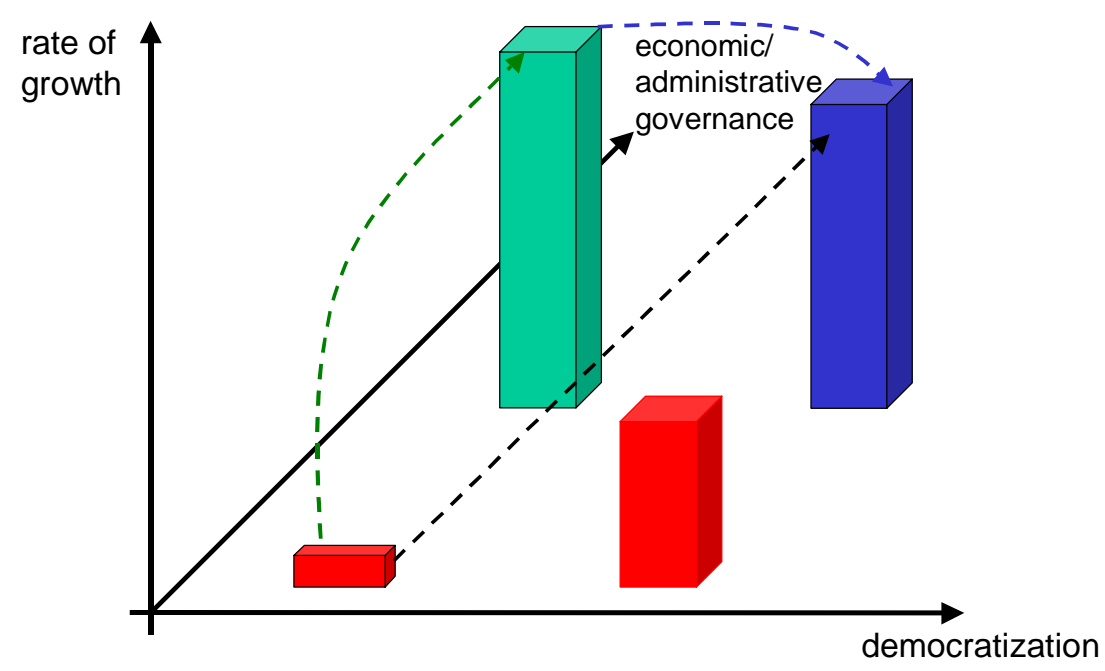

Source: author.

What is remarkable about these developments in successful transition economies is that especially the Asian economies in transition crafted effective institutions of economic and administrative governance which improved the quality of public policymaking, enhanced private sector development and market exchange, but did not undermine the power of incumbent governments. Contrary to most European transition countries, democratization played a minor if any role in this process - similar to the process of long-term development in countries such as South Korea, Taiwan, Singapore, or Malaysia between the early 1960s and today.

On the contrary, in the transition countries which acceeded the European Union in 2004, the processes of strengthening governance and fostering democratizaion coincided. This can be attributed inter alia to the historical factors, cultural values, but also to the fact that the European Union as an external anchor to transition forced these transition economies to adopt the so-called acquis communautaire before they joined the Union. Thus, while this group of countries pursued a linear path of reform and transition as portrayed in Figure 3, the Asian countries (as well as today's advanced countries such as Germany or Chile) chose a 'roundabout way' in order to realize high economic growth rates as well as social achievements such as lower poverty rates. 
Without engaging immediately in democratization steps, they built strong governments which could rely on effective administrative and econonmic governance structures. For these countries, this development trajectory proved to be sustainable. And as the example of Germany in the late $19^{\text {th }}$ century or the cases of Chile (since the mid 1970s), Germany (after the $2^{\text {nd }}$ World War), South Korea and Taiwan (since the early 1960s) indicate, such a development path can (or will) eventually lead to more democratic structures in the course of time.

Whether or not a country is better suited to follow the linear trajectory or the 'roundabout way' as depicted in Figure 4, depends on that country's economic starting position, its historical legacy, its internal power structure and the incentives faced by its leadership. For North Korea, the linear development path is simply not feasible under its current leadership. This path would be an option (probably the only one), if the country collapses and will be absorbed by South Korea. However, if we think about the reform options of the Kim Jong-il regime, going the 'roundabout way' remains to only viable reform choice.

\section{Reforming North Korea? - Getting from 'here' to 'there'}

Throughout the 1990s and the present decade, North Korea has been plagued by continuous economic decline and a gradual breakdown of the centrally planned economic system (Seliger 2006a and b). In order to avoid a complete economic collapse, the leadership will be forced to give up its muddling-through strategy and to undertake more serious economic reforms. Due to existing political restrictions and interests, reform steps cannot question the political system or the power of the leadership. But in order to survive domestic, market-oriented economic reforms are unalterable, and they will need to be complemented by cautious attempts at opening up the economy, especially towards South Korea, China, Vietnam as well as Russia and possibly some other politically neutral states. The conditio sine qua non for effective reforms is the emergence of a MEGS, which is to be adapted to the specificities of today's North Korea. Thus, reforms must not be restricted to economic restructuring. They need also aim at strengthening the government apparatus in order to prepare the administration to implement economic policies. They should show certain minimum measures which can limit a strong government in order to enhance authorities' reputation and credibility, and they ought to support capacity building in the public sector. 


\section{Economic institution building}

Domestic economic reforms need to aim at increasing the allocative and dynamic efficiency of the economy through macroeconomic stabilization, more flexible prices and wages, and competition which together may adequately flank and secure a badly needed sectoral restructuring. Emphasis should be given to a more liberalized agricultural sector and more generally rural development, in order to overcome famine and poverty. In addition, the emergence of small and medium-sized enterprises (SMEs) should be promoted in order to create jobs, enjoy productivity gains, and to smoothen industrial restructuring overcoming the heavyindustry bias.

Since, however, reform and transition will only succeed if the number of losers from economic restructuring is small or if losers will be compensated, continuous government intervention into economic reform processes will be required. This is essential for two reasons: (1) a too fast transition and withdrawel of the government would entail a strong J-curve effect in production so that compensation of losers will be hardly possible; (2) policymakers themselves need to be winners from reform. Therefore, incumbent policymakers as well as masses of ordinary people need to be temporarily protected from the drawbacks of marketization. At the same time, these groups of actors need to be provided with incentives to change their economic routines and behavior.

Thus, a complete price liberalization will not be politically feasible in North Korea, because it would contradict the interests of the political leadership. Similarly, although privatization of state-owned enterprises (SOEs) is a critical step in transforming a centrally-planned into a market economy, large-scale privatization will not be feasible in the short run. This could hardly be justified within the present Juche framework and would take the government into an ideological cul-de-sac. Moreover, due to the fact that much of the industrial capital stock will be rendered obsolete in the course of economic transition, a quick large-scale privatization would, in the absence of (foreign) investment capital, lead to numerous bankruptcies (or continuing massive government subsidies). This, in turn, would threaten to undermine emerging confidence in the functioning of market forces and could impede overall economic reform. In this context, it may be more promising to legalize and extend already existing small-scale private transactions as 
conducted on farmers markets and in the retail sector. ${ }^{10}$ Promoting newly emerging small and medium sized enterprises and hence creating a labor-intensive private sector gradually in a bottom-up manner could reinforce a (partial) price liberalization, support a badly needed supplyside reaction of the economy, and foster job creation. This, in turn, would help to absorb labor that will be laid off in the course of agricultural and industrial restructuring.

In that context, a dual-track approach to reform, Chinese-style, may help to maintain unproductive rents for some transitional period, while setting incentives to engage in market exchange, in order to enjoy extra profits in case of market success. ${ }^{11}$ Such a dual-track approach can be applied to industrial restructuring long before state-owned enterprises are privatized. It can be also applied to financial-sector reform, before financial transactions are fully liberalized or banks privatized. It could be even introduced in the agricultural sector if farmers are supposed to deliver their produce according to plan figures, but may sell any amount of surplus production at market prices. Even with respect to regime elites such as the military, such an approach may prove to be attractive: (1) the power of the elite will not be undermined; (2) the leadership will maintain its political power; and (3) the military (and possibly other priviledged actors) can enjoy increasing profits in their business activities in which they have been involved for a long time. Finally, a dual-track approach can also be applied in opening up the economy towards South Korea, China, and other countries. Long before institutions such as free trade areas or a customs union will be politically feasible, North Korea could cautiously, temporarily, and partially expose parts of its economy to the outside world through one-off projects and particulary the establishment of special economic zones. ${ }^{12}$

A dual-track approach in North Korea would not only help to gradually overcome obstacles to industrial reform, it would also be a reform, that could be ideologically digested. Furthermore, it would be consistent with a gradual opening strategy towards South Korea and third countries. Moreover, such an approach neither requires a complete price liberalization nor the introduction of full currency convertibility nor a large-scale privatization of SOEs. Nevertheless, it would be possible (and necessary) to create competition under a dual-track approach: by fostering the emergence of private businesses in sectors such as agriculture, retail trade, and light

\footnotetext{
10 According to estimates of South Korea's Ministry of Unification, more than 300 'unofficial' markets exist, which meet more than $70 \%$ of the urban population's consumption needs (Babson 2001b).

11 Regarding possible counterarguments regarding a dual-track approach in North Korea see, e.g., Ahrens (2006a).

12 With respect to the challenge and possible strategies to open up the economy see, e.g., Ahrens (2006a).
} 
manufacturing, strengthening the corporate-control structures of, and introducing hard budget constraints for, SOEs (in addition, they may be put under the authority of regional or local administrations similar to China's so-called township and village enterprises). Finally and most important, this approach does not presuppose major political change.

\section{Enhancing state strength for implementing economic reforms}

In North Korea, authority is vested in persons, not to say in one (!) person - not in rules, and a shift to a rule-of-law state cannot be expected under current political conditions. How can North Korea become a strong state in the sense that it is capable of implementing growth-enhancing economic reforms, protecting property rights, and enforcing legal rights and contracts? States are considered strong if they show at least two characteristics which help to overcome problems of collective action: (1) they must be autonomous and hence shielded from the influence of vested interest groups in order to formulate policies independently; and (2) they need to exhibit sufficient degrees of centralization and internal cohesion in order to overcome collective action and principal-agent problems and to implement policies effectively (Doner 1992).

Assuming that the Kim Jong-il regime actually intends to gradually open up and reform its economy, the notion of the developmental state, that underlay the economic development processes in several high-performing Asian economies in the 1960s and 1970s, may offer some pointers of how to enhance state strength for economic policy making. The most essential features of a developmental state comprise: (1) stable political rule ensured by a politicaladministrative elite that does not accede to political pressures which could impede economic growth; (2) cooperation between the public sector and the economy that is guided by an economic planning agency; (3) investment in universal education and policies aiming at a more equitable distribution of opportunities and wealth; and (4) a government whose members understand the need for market-conforming policies and interventions (Johnson 1987, 1999).

A most critical characteristic of a strong (developmental) state is the necessity to ensure the autonomy of both the economic bureaucracy and the political elite who are in charge of strategy formulation and economic policy making. Hence, public sector reform, particularly public administration reform, is a key governance issue in order to strengthen the state apparatus, which has to be addressed at an early stage of the reform process. It concerns the core institutions of government and includes (i) strengthening of central mechanisms for economic policy formulation, coordination, and implementation; (ii) public financial management reform 
including strengthening audit capacity; and (iii) civil service reform. Economic reform and transition call for new kinds of professional and managerial expertise. Strong and effective institutions are needed to perform market-friendly government functions including the provision of public goods and a legal and regulatory framework for market transactions, protection of property rights, and contract enforcement.

However, administrative professionalism is only a necessary, not a sufficient condition for effective policy reform. Other institutional key features of public administration reform include the replacement of political appointments and dismissals by the introduction of meritocratic standards in promotion and in recruitment, providing civil servants with opportunities for longterm career rewards, and setting transparent rules for hiring and firing. ${ }^{13}$

Finally, state strength also depends on the legitimacy of the political regime. An interesting facet of the recently emerged 'new thinking' is that even the Juche doctrine has been subject to reinterpretation. As Kim Jong-il stated in May 2001: "We should have a correct understanding of self-reliance. The nature of self-reliance we referred to in the past is qualitatively different from the one we refer to know" ${ }^{\prime \prime 14}$, namely enhancing efficiency and promoting technology. A gradual shift in political articulation and action toward a 'socialist market-based economy, North-Korean style' and the overall goal to pursue 'growth and prosperity of the Fatherland' may in fact help the political elite to undertake gradual economic reforms under the umbrella of socialism without losing its face.

\section{How to limit state strength in the Kim Jong-il regime?}

In advanced countries with developed market economies, state strength is usually limited through a subtle system of checks and balances, a horizontal and vertical separation of power, free and general political elections, appropriate state-business-society interfaces, the work of independent domestic NGOs and watchdog organizations, or systems of market-preserving federalism. But none of these options appears to be available in today's North Korea. If, however, a strong North

\footnotetext{
${ }^{13}$ For making meritocratic personnel policies work, governments need to place strong emphasis on education policies in order to create a pool of highly qualified potential civil servants. Note in this context that, although establishing effective economic bureaucracies is a complex task, it is not as time-consuming and difficult as one might expect. Countries as diverse as South Korea and Taiwan or France and Austria, whose bureaucracies were considered to be incompetent, ineffective, and non-meritocratic in the first half of the 20th century and even into the 1950 s, managed within some 20 years to establish high-quality public administrations through comprehensive civil service reforms; see, e.g. Chang and Cheema (2002).

14 Yi Yong-Hwa, "Important Conditions for Promoting Self-Reliance," Minju Choson, May 16, 2001; quoted in Hassig and Oh (2002: 98).
} 
Korean state is an unalterable precondition for effective market-oriented reforms, what would be a suitable mechanism to limit such a possibly emerging strong government? One approach would be that the government binds its own hands at least with respect to specific policy realms and imposes limits upon its activities (e.g., through establishing an independent central bank in the course of a gradual reform program). At present, this option cannot be realistically expected, although its realization may become feasible in the long run. The only currently feasible alternative is to establish limits on the government through an external flanking of North Korea's reform and integration process (Ahrens 2006a). Even if the engagement and international involvement of the DPRK is an imperfect disciplining device, it may be appropriate to provide the Kim Jong-il regime with incentives to conduct domestic economic reforms. Gradually opening up the economy and increasing its exposure to foreign competition as well as membership in international organizations such as the World Bank and the ADB and hence the obligation to abide by these organizations' rules and policies might slowly help to make a potential commitment to reform credible.

\section{Building capacity for effective public policies}

A systematic and coherent approach to constitute a MEGS in North Korea must go beyond measures to foster human resource development and seek to reform existing and to craft new institutions, which perform core governance functions. Sector-specific steps to overcome weaknesses in governance must be supplemented by cross-sector and macro-level attempts. For example, in the absence of a sound macroeconomic policy framework, initiatives at the sector level will not yield the desired results. Similarly, since the structure of the public administration imposes a uniform stamp on all public agencies, a broad macro-level attempt to resolve the administrative impediments is needed to increase the chances of efficient project implementation and the benefits to a wider segment of society.

Given these interdependencies, the reform of the economic bureaucracy will be more effective if it is approached wholesale. Since measures such as higher salaries, performancebased employment, downsizing of surplus staff, and organizational restructuring are central to improving the implementation capacities of weak executing agencies, it is necessary to complement sector-level capacity building with measures that must be applied to the public administration in its entirety. This appears to be even more important if one considers that implementation depends not just on line agencies but also on the ministries and departments that 
oversee their work. It is these civil servants, directly under the political leadership, that allocate resources, and take or influence the decisions that critically determine the outcome of economic projects and policies. Much more so than in the case of line agencies, reforming these core government functions requires integrated approaches focusing on the public administration as a whole.

A systematic approach to overcome major institutional and structural impediments to sound and market-oriented economic management would, e.g., include:

- the introduction of hard budget constraints in the public sector;

- strengthening personnel management through merit-based recruitment and promotion schemes;

- competitive wages for bureaucrats that can increase integrity and professionalism;

- independent personnel agencies which reduce external pressure on appointments and patronage;

- effective accounting and auditing practices to enhance the financial accountability of policy makers;

- statutory boards partitioning the policy space by assigning single policies to special agencies that help monitor bureaucratic performance;

- publication of government documents and data (e.g., rules and statutes, budgets, and revenues);

- anti-corruption agencies which reduce bureaucrats' propensity to use their specific information for extra-legal activities;

- improving and enforcing legal and regulatory frameworks;

- clarification and institutionalization of the relations between the central government and local authorities; and

- establishing institutionalized linkages to the nascent private sector and promoting its development.

Such steps aiming at public administration reform would not threaten the political regime per se, so that their realization appears to be feasible even in the North Korean context. To be effective, however, institutional and organizational reforms must be accompanied by improvements in human resource development, the more so as knowledge of market economics and modern management techniques is virtually absent in North Korea. Moreover, civil servants have been used to follow directives from their superiors and discouraged to take own initiatives, to 
cooperate horizontally across government departments, to report deficiencies of the administrative system, or to make suggestions for its improvement. Therefore, bureaucrats need to develop new behavioral routines and work ethics, which may be facilitated through investment in human resource development. In this context, it is of utmost importance to strengthen the overall education system and to accept technical assistance, which can be provided by international organizations such as the ADB or the United Nations Development Programme. More specifically, one may, e.g., think of cost-effective and sustainable measures such as hiring long-term foreign consultants for on-the-job training, study tours and long-term training abroad, seminars and workshops on market economics and modern management techniques, which enhance skills and improve the communication among public officials, and train-the-trainers programs due to huge number of training and capacity building needs. In order to ensure that the North Korean government can assume full ownership of any reform program, capacity building measures, which are conducted in collaboration with foreign consultants or international organizations, need to be based on commonly understood goals possibly embodied in a memorandum of understanding, and donor organizations and their North Korean counterparts should jointly develop a road map for projects and reform programs.

\section{Conclusion: towards a reforming North Korea?}

How to craft a market-enhancing governance structure that is suitable as a politico-institutional foundation of effective economic transition? The preceding considerations showed that basic elements of governance structures can be manipulated or crafted by political means. However, policymakers, bureaucrats or other actors affecting the design of a governance structure can never completely anticipate all future contingencies. Furthermore, numerous actors affect governance structures, either through comprehensive reforms such as restructuring a country's system of health insurance, or through smaller changes, e.g., firm-specific labor-market regulation. Usually, it is extremely difficult to ensure proper coordination of all actors, sometimes actors may actually not be interested in cooperating at all. This implies that certain changes in a country's governance structure can be consciously planned, but that the governance structure as a whole is subject to evolutionary change. It also follows that looking for best-practice governance or transferring 
governance structures from one country to another will be doomed to fail; the more so as such a transfer could not account for existing cultural endowments and the stock of social capital.

Even in the successful transformation countries, governance structures are not perfect. But in each case, they exhibit key characteristics which help to enhance government commitment to economic growth and development. In all those countries, numerous institutions underlying the governance structure show a comparatively high quality; either because countries such as the new EU member states have sought to implement Western best-practice institutions (which in their cases materialized) or, as in the case of China, because effective transitional institutions could be crafted which represented functional equivalents to orthodox market institutions.

Moreover, singular events (such as Deng Xiaoping's tour through South China in 1992 which gave the transition process a new, maybe a critical impetus) or the historical moment in which a country finds itself (such as the breakdown of the Berlin Wall and the option for many countries in CEE to return to Europe) may crucially affect a society's development trajectory. Even in those situations, which may be basically favorable to economic transition and development, success is far from clear. Singular events and favorable historical moments may serve as trigger or catalyst, but they cannot substitute for good institutions and determined political leadership. The existence of policymakers who seize those opportunities and seek to craft a politico-institutional foundation, which helps to make effective market-oriented reforms a viable policy choice, are an unalterable precondition to successful transition.

Finally, the main findings of the preceding considerations can be synthesized as follows: First, governance can viewed as a dynamic process, and policymakers need to take care that policies match institutions et vice versa. MEGS are subject to change over time; they require permanent fine tuning and adapting institutions as well as policy solutions to changing social, economic, and political environments.

Second, the capability of crafting and adopting country- and time-specific institutional structures is as important to effective governance as the formulation of policies. Which institutions are suitable depends on the stage of economic and political development as well as on persisting informal institutions.

Third, political legitimacy is an indispensable prerequisite for an emerging societal consensus in favor of distinct transition strategies. 
Fourth, credibility, an independent, but accountable administration, and social consensus favor the emergence of a strong but limited government that guarantees political stability and increased governance capacity.

Fifth, a Western-style democracy is not a universal model of development or a precondition to economic transition; effective governance is independent of the form of government.

Sixth, while the initiation of policy and institutional reform can be facilitated by discretionary authority of policymakers and political institutions which shield policymaking from the influences of vested interests, their consolidation presupposes stable expectations with respect to the new institutional matrix underpinning the market system, and private actors must be confident that these rules cannot be arbitrarily changed or violated by the government and its agents.

These considerations illustrate again that a universal MEGS does not exist. But the ultimate objective of crafting flexible governance structures is the same in all countries, namely to establish strong but limited governments which are embedded in institutional structures that are conducive to promoting the quality of the core dimensions of effective governance.

\section{References}

Acemoglu, Daron, Johnson, Simon and Robinson, James (2004), "Institutions as the fundamental cause of long-run growth”, NBER Working Paper No. 10481. Cambridge, Mass: NBER.

Ahrens, Joachim (2006a), "Market-enhancing governance on the Korean peninsula: the role of credibility and transitional institutions", North Korean Review, Vol. 2, No. 1, 2006.

Ahrens, Joachim (2006b), “ Governance in the process of economic transformation. In S.-J. Park, B. Seliger (eds.), System Transformation in Comparative Perspective. Münster: LITVerlag (forthcoming).

Ahrens, Joachim (2002), Governance and Economic Development. A Comparative Institutional Approach. Cheltenham: Edward Elgar.

Ahrens, Joachim and Meurers, Martin (2002), "How Governance Affects the Quality of Policy Reform and Economic Performance: New Evidence for Economies in Transition", Journal for Institutional Innovation, Development and Transition (IB Review), Vol. 6.

Bardhan, Pranab (2005), “Institutions Matter, But Which Ones?” Economics of Transition, 13(3), pp. 499-532.

Chang, Ha-Joon (2002), Kicking Away the Ladder -Development Strategy in Historical Perspective. London: Anthem Press.

Debiel, Tobias, Klingebiel, Stephan, Mehler, Andreas, and Schneckener, Ulrich (2005), "Between Ignorance and Intervention. Strategies and Dilemmas of External Actors in Fragile States", Development and Peace Foundation Policy Paper, Bonn 2005.

Ebner, Alexander (2005), “Governance," forthcoming in: O’Hara, Phil (ed.), International Encyclopedia of Public Policy: Governance in a Global Age, London and New York: Routledge.

Eucken, Walter (1990/1953), Grundsätze der Wirtschaftspolitik, (6 ${ }^{\text {th }}$ revised edition). Tübingen: J.C.B.Mohr (Paul Siebeck). 
Evans, Peter (1995), Embedded Autonomy: States and Industrial Transformation. Princeton, NJ: Princeton University Press.

Feng, Yi (2003), Democracy, Governance, and Economic Performance: Theory and Evidence, Cambridge, MA and London: The MIT Press.

Grindle, Merillee S. (1997), "The Good Government Imperative: Human Resources, Organizations, and Institutions", in: Grindle, Merilee (ed.), Getting Good Government: Capacity Building in the Public Sectors of Developing Countries. Boston, MA: Harvard University Press.

Kaufmann, Daniel, Kraay, Aart and Mastruzzi, Massimo (2003), 'Governance Matters III: Governance Indicators for 1996-2002’, World Bank Policy Research Working Paper No. 3106, Washington, DC: The World Bank.

Kaufmann, Daniel, Kraay, Aart and Zoido-Lobatón, Pablo (1999), 'Governance Matters', World Bank Policy Research Working Paper No. 2196, Washington, DC: The World Bank.

Kaul, Inge (2001), "Public Goods: Taking the Concept to the Twenty-First Century," in: Drache, Daniel (ed.), The Market or the Public Domain: Global Governance and the Asymmetry of Power, London and New York: Routledge, pp. 255-273.

Khan, Mushtaq H. (2002), "State Failure in Developing Countries and Strategies of Institutional Reform", paper presented at the ABCDE Conference Europe, Oslo 2002.

Maass, Gero and Mepham, David (2004), Promoting Effective States. A progressive policy response to failed and failing states. Friedrich-Ebert-Stiftung and Institute for Public Policy Research, London.

Murrell, Peter (1995), “The transition according to Cambridge, Mass.”, Journal of Economic Literature, Vol. 33, No. 1, pp. 164-178.

Myrdal, Gunnar (1989), "The Equality Issue in the World Development: Nobel Memorial Lecture, March 17, 1975", The American Economic Review, Vol.79, No.6, pp.8-17.

North, Douglass C. (1997), "The Contribution of the New Institutional Economics to an Understanding of the Transition Problem," WIDER Annual Lectures, Internet: http:/www.wider.unu.edu/publications/annuallectures/annua-lecture-1997.pdf

North, Douglass C. (1990), Institutions, Institutional Change and Economic Performance, Cambridge: Cambridge University Press.

Qian, Yingyi (2003), "How Reform Worked in China", in Rodrik, Dani (ed.), In Search of Prosperity. Analytic Narratives on Economic Growth. Princeton and Oxford: Princeton University Press, pp. 297-335.

Qian, Yingyi (1999a), "The Institutional Foundation of China's market transition”, Paper prepared for the World Bank's Annual Conference on Development Economics, Washington, D.C., April 28-30, 1999. Internet: http://www-econ.stanford.edu/faculty/workp/swp99011.pdf.

Qian, Yingyi (1999b), “The Process of China's Market Transition (1978-98): The Evolutionary, Historical and Comparative Perspectives", paper prepared for the Journal of Institutional and Theoretical Economics symposium on "Big-Bang Transformation of Economic Systems as a Challenge to New Institutional Economics," June 9-11, 1999, Wallerfangen/Saar, Germany, Internet: http://wwwecon.stanford.edu/faculty/workp/swp99012.pdf.

Roland, Gérard (2004), "Understanding Institutional Change: Fast-Moving and Slow-Moving Institutions," Studies in Comparative International Development, Vol. 38, No. 4, pp. 109-131.

Roland, Gérard (2000), Transition and economics: politics, markets, and firms. Cambridge, MA: The MIT Press.

Root, Hilton (2001), ”Do Strong Governments Produce Strong Economies?”, The Independent Review, Vol.5, No.4, pp. 565-573.

Seliger, Bernhard (2006a), "Monetary and Exchange Rate Policy in Declining Centrally-Planned Economies and in Early Transition: Some Observations in the case of North Korea", paper presented at Seventeenth U.S.-Korea Academic Symposium "Dynamic Forces on the Korean Peninsula: Strategic \& Economic Implications", September 25 - 27, 2006 Harvard University, John F. Kennedy School of Government, Cambridge, Massachusetts. 
Seliger, Bernhard (2006b), "Income, Wealth and Political Power in an uneven Transformation Process - the Case of North Korea", North Korea Review, Vol. 2, no. 2.

Streit, Manfred E. and Wohlgemuth, Michael (1997), "The Market Economy and the State - Hayekian and Ordoliberal Conceptions", prepared for the Fifth Annual SEEP-Conference on Economic Ethics and Philosophy, Section I, Marienrode 29 October - 1 November 1997, Internet: http://www.dundee.ac.uk/cepmlp/journal/assets/images/Streit-onHayek97.pdf.

Varga Llosa, Alvaro (2005), "The Failure of States". Internet: http://www.globalpolicy.org/nations/sovereign/failed/2005/0908failure.htm; accessed 8 December 2006.

Wagener, Hans-Jürgen (2004), "Good Governance, Welfare, and Transformation,“ European Journal of Comparative Economics, Vol. 1, No. 1, pp. 127-143.

Williamson, Oliver E. (1985), The Economic Institutions of Capitalism. Firms, Markets, Relational Contracting, New York: The Free Press.

Williamson, Oliver E. (1995), “The Institutions and Governance of Economic Development and Reform", in: Michael Bruno and Boris Pleskovic (eds), Proceedings of the World Bank Annual Conference on Development Economics 1994, Washington, DC: The World Bank, pp. 171-197.

Woodward, Susan L. (2006), "Failed states: The power of words". Internet: http://www.enjeuxinternationaux.org/articles/num11/en/failed.htm; accessed 8 December 2006.

World Bank (2000), Reforming Public Institutions and Strengthening Governance, Washington, DC: The World Bank. 